ISSN 1814-1196

Научный вестник НГТУ

том 77, № 4, 2019, с. 31-44 http://journals.nstu.ru/vestnik

Science Bulletin of the NSTU

Vol. 77, No. 4, 2019, pp. 31-44

\author{
ИНФОРМАТИКА, \\ ВЫЧИСЛИТЕЛЬНАЯ ТЕХНИКА \\ И УПРАВЛЕНИЕ
}

\author{
INFORMATICS, \\ COMPPUTER ENGINEERING \\ AND MANAGEMENT
}

UDC 004.94

DOI: 10.17212/1814-1196-2019-4-31-44

\title{
Determination of the effect of injection wells on production wells in their work dynamics by using hydrodynamic modeling
}

\author{
A.M. GRIF ${ }^{a}$, M.G. PERSOVA ${ }^{b}$, Y.G. SOLOVEYCHIK ${ }^{c}$ \\ Novosibirsk State Technical University, 20 K. Marx Prospekt, Novosibirsk, 630073, Rus- \\ sian Federation \\ a alexgrif@inbox.ru ${ }^{b}$ persova@ami.nstu.ru ${ }^{c}$ soloveychik@ami.nstu.ru
}

We consider a method for determining a mutual influence of a group of production and injection wells using a module of hydrodynamic modeling. The obtained results of this mutual influence are widely used in practice - from maintaining the reservoir pressure to an effective optimization of water flooding. To simulate the process of multiphase mixture filtration we use the finite element method and a specific technology that allows balancing flows across cell boundaries of the finite element mesh. The balancing method is based on the selection of corrective additives that satisfy the minimum functional of the balance of volumes of the filtered mixture with regularization. The model of mutual influence of wells uses the dependence of the wellhead pressure obtained as a result of hydrodynamic modeling, as well as volumes of an injected and/or taken-off mixture (with different signs). For a producing well of interest, the wellhead pressure is approximated by a function of the volumes of the injected mixture in a group of neighboring wells. Regression coefficients are calculated by the least squares method. The article also provides results of studies that consider the application of the method on three specific tasks that, in turn, emulate the operation of production and injection wells. To evaluate the degree of influence of a nearby well on a well of interest, a significance criterion is introduced in the form of ratios of residual sums of squared deviations. The calculation results indicate that the estimated effect of the wells corresponds to the physics of the process, which confirms the correctness of the developed procedure for analyzing the interaction of injection and production wells, and also indirectly confirms the correctness of the implementation of the module for direct problems solving. The creation of the hydrodynamic model, the calculations, as well as the analysis of the mutual influence of the wells is implemented interactively in an automated softwareinformation system.

Keywords: reservoir simulation, filtration, finite element method, balancing flows, wells interaction, regression, influence, information system

\footnotetext{
${ }^{*}$ Received 15 October 2019.
} 


\section{INTRODUCTION}

Today improving the quality of production processes in the oil industry is challenging without the use of high-tech software that allows building a digital model of the deposit, carrying out three-dimensional modeling and making interactive analysis of the results. Software systems of this kind should be based on the use of three-dimensional mathematical models that reflect the fundamental laws of physics, in particular hydrodynamics [1,2]. Also, a very important task is to determine the mutual influence of production and injection wells. The obtained results of mutual influence are actively used in practice, for example, for maintaining reservoir pressure, or conducting effective water flood optimization [3].

The existing specialized software systems for modeling (e.g., ECLIPSE [4], RSM [5], etc.) use the finite volume method, due to which a balanced solution is obtained (observing the law of mass balance) [6]. However, it has a number of disadvantages for modeling areas with curved boundaries. Also, most studies to determine the mutual influence of wells use methods of mathematical statistics, or some heuristic approaches. However, a formal calculation of the mixture (or oil) withdrawal values at the producing well using a group of neighboring wells is not a universal approach, even with simple model examples. Besides the use of additional data on the spatial orientation of wells and the construction of diagrams taking into account environmental parameters does not allow achieving any acceptable results [7].

\section{STATEMENT OF THE PROBLEM}

Since one of the main requirements for hydrodynamic modeling systems is to comply with the law of mass conservation, numerical schemes based on the finite volume method are quite common. This method is based on the balance of flows across cell boundaries of a discrete model.

At the same time the finite element method (FEM) allows us to use a much more heterogeneous object geometry which is typical to describe the reservoir and wells geometry in this class of problems. Moreover, a formal application of FEM in the Galerkin formulation does not ensure compliance with the mass conservation law [8-10]. Therefore, modifications are most commonly used for practical applications [11]. However, this approach entails an enormous computational cost due to the use of very detailed spatial meshes to obtain solution convergence.

In this paper we will describe an approach to the use of the finite element method, which guarantees the implementation of conservation laws and does not impose additional requirements on the spatial mesh fineness. Also, a description will be given of a method based on this approach to determine the influence of injection wells on production wells using data on the injection volume, production volume and pressure on production wells.

\section{FINITE ELEMENT APPROXIMATION}

The process of a multiphase flow of an incompressible fluid in the isothermal area $\Omega$ can be described by a system of differential equations [12]

$$
-\operatorname{div}\left(\rho^{m} \vec{u}^{m}\right)=\frac{\partial}{\partial t}\left(\Phi \rho^{m} S^{m}\right)+\tilde{f}, m=\overline{1, M},
$$




$$
\vec{u}^{m}=-\mathbf{K} \frac{\kappa^{m}}{\eta^{m}} \operatorname{grad}\left(P+P_{c}^{m}\right), m=\overline{1, M},
$$

where $\vec{u}^{m}$ is a filtration velocity of the $m$ phase in porous media (Darcy's law); $S^{m}$ is the saturation of the $m$ phase; $\eta^{m}$ is dynamic viscosity; $\kappa^{m}$ is relative permeability; $\rho^{m}$ is phase density; $P$ is pressure; $P_{c}^{m}$ is the capillary pressure phase; $\tilde{f}$ is the production or injection of the phase in the field; $\Phi$ is the structure of porous rocks, and $\mathrm{K}$ is structural permeability rocks.

With constant values of $\Phi, K$ and $\rho^{m}$ equations (1) - (2) can be converted into the problem [13]

$$
-\operatorname{div}\left(\sum_{m=1}^{M} \mathbf{K} \frac{\kappa^{m}}{\eta^{m}} \operatorname{grad}\left(P+P_{c}^{m}\right)\right)=0
$$

with boundary conditions

$$
\begin{gathered}
\left.P\right|_{\Gamma_{1}}=P_{g} \\
\left.\sum_{m=1}^{M} \mathbf{K} \frac{\kappa^{m}}{\eta^{m}} \frac{\partial P}{\partial n}\right|_{\Gamma_{2}}=\theta
\end{gathered}
$$

where $\Gamma_{1}$ is far lateral boundaries of the domain $\Omega ; \Gamma_{2}$ is an impermeable boundary with $\theta=0$ and the boundaries of the wells through which the production or injection of the mixture is specified.

Problems (3) - (5) will be solved using the finite element method to discretize this $\Omega$ area to $\Omega_{e}$ cells. In each cell the rock and mixture parameters are constant. The pressure function $P$ can be represented as the decomposition of linear basis functions $\psi_{i}$ :

$$
P=\sum_{j} p_{j} \psi_{j}
$$

The weight decomposition $p_{j}$ can be found by solving sparse linear tems [14]

$$
\mathbf{A p}=\mathbf{b},
$$

where $\mathbf{p}$ is a vector of unknown weights while components of the matrix $\mathbf{A}$ and the vector $\mathbf{b}$ of the right side are defined by the relations

$$
A_{i j}=\int_{\Omega}\left(\mathbf{K} \sum_{m=1}^{M} \frac{\kappa^{m}}{\eta^{m}} \operatorname{grad} \psi_{j}\right) \operatorname{grad} \psi_{i} d \Omega,
$$




$$
b_{i}=\int_{\Gamma_{2}} \theta \psi_{i} d \Omega-\int_{\Omega}\left(\mathbf{K} \sum_{m=1}^{M} \frac{\kappa^{m}}{\eta^{m}} \operatorname{grad} P_{c}^{m}\right) \operatorname{grad} \psi_{i} d \Omega .
$$

We make an approximation of the fluid flow across boundaries $\Gamma_{i}$ of the cell area $\Omega_{e}$. For this we calculate the filtration velocity

$$
\vec{u}_{\Gamma_{i}}=-\mathbf{K} \sum_{m=1}^{M} \frac{\kappa^{m}}{\eta^{m}} \operatorname{grad}\left(\sum_{j} p_{j} \psi_{j}+P_{c}^{m}\right),
$$

according to which the volumes of the filtered mixture can be calculated on the face $\Gamma_{i}$ of the finite element $\Omega_{e}$ :

$$
Q_{\Gamma_{i}}=\int_{\Gamma_{i}} \vec{u}_{\Gamma_{i}} \cdot \vec{n}_{\Gamma_{i}} d \Gamma
$$

where $\vec{n}_{\Gamma_{i}}$ is a normal vector to the face $\Gamma_{i}$. The flow direction is defined by the value $S g_{\Gamma_{i}} \Omega_{e}$, which is equal to 1 if $Q_{\Gamma_{i}}$ flows into the element $\Omega_{e}$ and is equal to -1 if $Q_{\Gamma_{i}}$ flows out.

The flowing volume can be different on both sides of the face, and the flowing volume may not be equal to the flowing volume, due to an error in the numerical solution Therefore, we will use the balancing process flows for the averaged volume on the face $\hat{Q}_{\Gamma_{i}}$.

Let us find such corrective additives $\delta Q_{i}$ (where $i$ is the global number of faces) for each finite element, that they, on the one hand, minimize the total system unbalance, and, on the other hand, are close to the calcuated numerical flow. These corrective additives can be found as a result of $\delta Q_{i}$ minimization following the functional [15]:

$$
\sum_{e=1}^{N^{e}} \beta_{e}\left(\sum_{i \in I_{\Omega_{e}}}\left(S g_{\Gamma_{i}}^{\Omega_{e}} \cdot\left|\hat{Q}_{\Gamma_{i}}\right|+S g_{\Gamma_{i}}^{\Omega_{e}} \cdot \delta Q_{i}\right)\right)^{2}+\sum_{i=1}^{N^{f}} \alpha_{i}\left(\delta Q_{i}\right)^{2},
$$

where $e$ is the number of the finite element; $I_{\Omega_{e}}$ is a set of faces $\Gamma_{i}$ of the finite element $\Omega_{e} ; N^{e}$ and $N^{f}$ are numbers of finite elements and faces; $\beta_{e}$ and $\alpha_{i}$ are parameters. The parameter values $\beta_{e}$ should be chosen as small as possible but still they should ensure the required imbalance $\delta Q^{\text {crit }}$ :

$$
\sum_{e=1}^{N^{e}} \beta_{e}\left|\sum_{i \in I_{\Omega_{e}}}\left(S g_{\Gamma_{i}}^{\Omega_{e}} \cdot\left|\hat{Q}_{\Gamma_{i}}\right|+S g_{\Gamma_{i}}^{\Omega_{e}} \cdot \delta Q_{i}\right)\right|<\delta Q^{c r i t}
$$


As a result of minimizing the functional (8) to $\delta Q_{i}$ we get a system of linear equations

$$
(\mathbf{B}+\boldsymbol{\alpha}) \mathbf{q}=\mathbf{d},
$$

where $\mathbf{q}$ is a vector of unknown values $\delta Q_{i}, \boldsymbol{\alpha}$ is a matrix with elements $\alpha_{i}$, and components of the matrix $\mathbf{B}$ and vector $\mathbf{d}$ can be found by using the relations

$$
\begin{aligned}
& B_{i j}=\left\{\begin{array}{l}
2, i=j, \\
\beta_{e} \cdot S g_{\Gamma_{i}}^{\Omega_{e}} \cdot S g_{\Gamma_{j}}^{\Omega_{e}}, i, j \in I_{\Omega_{e}}, i \neq j, e=1 \ldots N^{e} \\
0, \text { else }
\end{array}\right. \\
& \quad d_{i}=-\sum_{e=1}^{N^{e}} S g_{\Gamma_{i}}^{\Omega_{e}} \cdot \sum_{j \in I_{\Omega_{e}}} \hat{Q}_{\Gamma_{j}, \Omega_{e}} .
\end{aligned}
$$

Rows/columns corresponding to the boundary conditions (5) on the faces of the mixture volume should be deleted from the system (9).

The balanced volume mixtures $\tilde{Q}_{\Gamma_{i}, \Omega_{e}}$ are defined as

$$
\tilde{Q}_{\Gamma_{i}, \Omega_{e}}=S g_{\Gamma_{i}}^{\Omega_{e}} \cdot\left|\hat{Q}_{\Gamma_{i}, \Omega_{e}}\right|+S g_{\Gamma_{i}}^{\Omega_{e}} \cdot \delta Q_{i, \Omega_{e}}
$$

Using the volumes of the mixture $\tilde{Q}_{\Gamma_{i}, \Omega_{e}}$ we can calculate the saturation distribution at the current time step. We denote by

$$
\tilde{Q}_{\Gamma_{i}, \Omega_{e}}^{m}=\tilde{Q}_{\Gamma_{i}, \Omega_{e}} \frac{\kappa^{m}}{\eta^{m} \sum_{n=1}^{M} \kappa^{n} / \eta^{n}}
$$

an instantaneous (per unit time) volume of the $m$ phase overflowing through the face $\Gamma_{i}$. Then during the time $\Delta t$ the volume of the $m$-th phase equal to

$$
V_{\Gamma_{i}, \Omega_{e}}^{m}=\left|\tilde{Q}_{\Gamma_{i}, \Omega_{e}}^{m}\right| \cdot \Delta t
$$

will overflow through the face $\Gamma_{i}$.

At the beginning of the time step, the volume of the $m$ phase in the cell $\Omega_{e}$ is

$$
\bar{V}_{\Omega_{e}}^{m}=\Phi \bar{S}^{m} \operatorname{mes}\left(\Omega_{e}\right)
$$

where $\bar{S}^{m}$ is the saturation of the $m$ phase at the beginning of the time step, and $\operatorname{mes}\left(\Omega_{e}\right)$ is the volume $\Omega_{e}$. 
Now we can determine the $m$ phase saturation at the end of the current time:

$$
S^{m}=\frac{\sum_{i \in I_{i n, \Omega_{e}}} V_{\Gamma_{i}, \Omega_{e}}^{m}-\sum_{j \in I_{\text {out }, \Omega_{e}}} V_{\Gamma_{j}, \Omega_{e}}^{m}+\bar{V}_{\Omega_{e}}^{m}}{\Phi \cdot \operatorname{mes}\left(\Omega_{e}\right)},
$$

where $I_{i n, \Omega_{e}}$ is a set of face numbers through which the mixture flows into $\Omega_{e}$, and $I_{o u t}, \Omega_{e}$ is a set of face numbers through which the mixture flows out from $\Omega_{e}$.

We will repeat the described process on each time layer.

\section{DETERMINATION OF THE INFLUENCE OF WELLS}

To determine an influence of injection wells on production wells it is proposed to use data on an average daily injection volume changing in time in injection wells, the production volume and pressure of producing wells.

According to the obtained solution (6) pressure on injection wells can be calculated as

$$
P_{k}=\sum_{j \in I_{W_{k}}} \int_{\Gamma_{j}} P_{\Gamma_{j}} d \Gamma / \sum_{j \in I_{W_{k}}} \int_{\Gamma_{j}} d \Gamma
$$

where $I_{W_{k}}$ is a set of face numbers $\Gamma_{i}$ of the $k$ injection well.

The pressure value (10) on the production well $W_{k}$ at the time $t_{i}$ can be approximated by the function $\tilde{P}_{k}$ of the volume $Q_{j}$ of the injected mixture on a group of neighboring wells:

$$
\tilde{P}_{k}\left(t_{i}\right)=a_{0}+\sum_{j=1}^{m} a_{j} Q_{j}\left(t_{i}\right)
$$

The normalized residual sum of squares of deviations (RSS) can be considered as a criterion of the proximity of the dependence $\tilde{P}_{k}$ to the function $P_{k}$. In this case, the coefficients $a_{0}, a_{1}, \ldots, a_{m}$ are found by the least squares method.

To assess the degree of influence of the $j$-th well let us introduce the value significance test (hereinafter - an influence coefficient) in the following form

$$
\chi_{j}=\left(R S S_{j}-R S S\right) / R S S,
$$

where the $R S S_{j}$ value is obtained by finding the $\tilde{P}_{y}$ function coefficients excluded from the $j$-th well.

The influence coefficient $\chi_{j}$ will be maximum for injection wells that have the greatest impact on the production well of interest. 


\section{SOFTWARE - INFORMATION SYSTEM}

For convenient creation of a hydrodynamic model of the field, as well as for viewing the obtained calculation results, a software-information system was developed. Fig. 1 shows a graphical interface of this system.

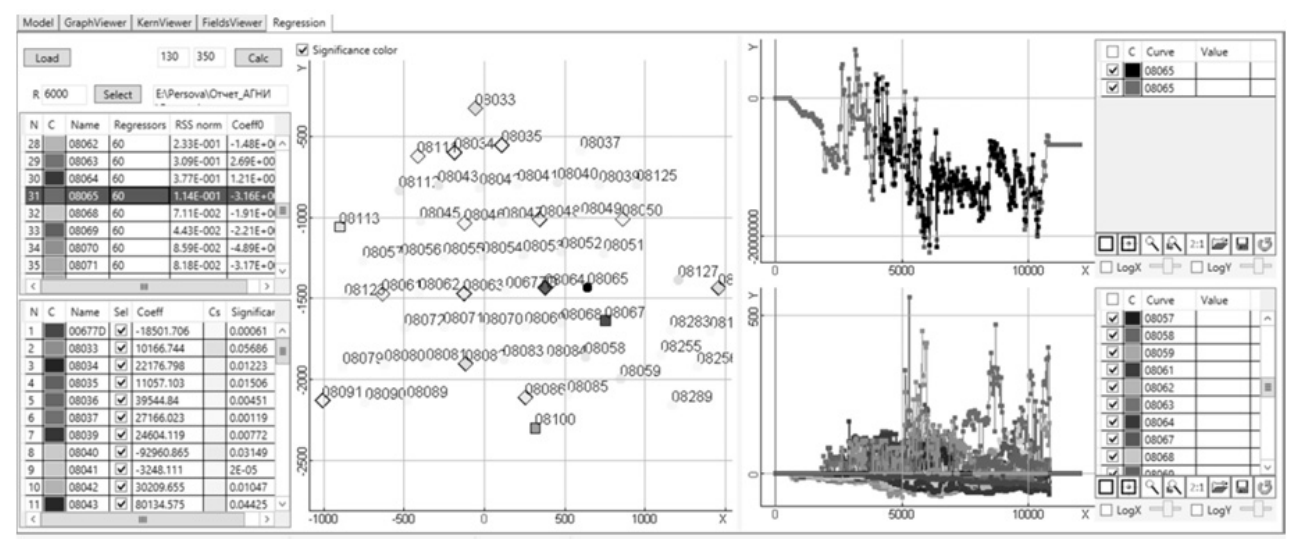

Fig. 1. Window view of the information system for determining the wells interference

Puc. 1. Вид информационной системы для определения взаимовлияния скважин

The system consists of three logical units. Elements of the input parameters for the analysis model, lists of production and injection wells with the characteristics of influence and control buttons are located in the left part of the GUI window. A graphical display of the wells in the plan (Oxy planes) in various color gradations is given in the center. A unit for displaying of characteristics of wells mutual influence is shown on the right. A circle is used to display wells in the center; a square is used to display injection wells, and a rhombus is used to display production wells which were converted into injection wells.

The list of analyzed production wells is presented in a table and contains the following information: the serial number of the well (column $\mathrm{N}$ ), the color of the well display (C), the identifier of the well (Name), the number of selected regressors or affecting wells (Regressors), a normalized residual sum of squares (RSS norm), and a free term (Coeff0).

When you click on the production well of interest, the list of influencing injection / produc wells is updated, which is also presented in the form of a table containing the following information: the serial number of the well (column N), the color of the well display (C), the identifier (name) of the well (Name),the mark of selecting this well in the analyzed model (Sel) (the system provides an ability to include/exclude individual wells from the analysis, and also to use for analysis only a group of wells located inside a circle with a radius (R), a linear regression coefficient for the given well (Coeff), the color of the well display by the degree of its influence on the studied production well (C), the influence coefficient reflecting the degree of influence of the current well on the analyzed production well (Significance).

The information system provides an ability to determine an influence of wells on the time interval of interest. To do this, you need to set two boundaries of the interval. At the top of the right block, the graphs of the initial pressure and the pressure on the production well in the selected time interval found by the proposed method are displayed (shown in black). At the bottom of the right block are graphs of injections and productions from all wells used in the analysis. They can be viewed separately (turning on/off the corresponding graph), and it is possible to change the scale. 


\section{COMPUTATIONAL EXPERIMENTS}

Testing of the developed module was carried out on synthetic data obtained using the module for solving direct problems.

Let us consider a three-layer model in which the first and third permeable layers are separated by impermeable interlayers (the model task was carried out using an automated system [16]). In this case, we consider three versions of this model. In the first case (model 1) a dividing interlayer is completely impermeable, but homogeneous permeability is set in the top and bottom layers (oil saturation distribution and location of wells are shown in Fig. 2, $a, b$ ) (oil saturation distribution and location of wells are shown in Fig. 2, $a, b$ ). In the second case (model 2) an impermeable "partition" is set in the upper layer (see. Fig. 2,c), while in the third case 3 (model 3) a permeable zone is set in the impermeable interlayer which separates the upper and lower layers (see. Fig. 2,d).

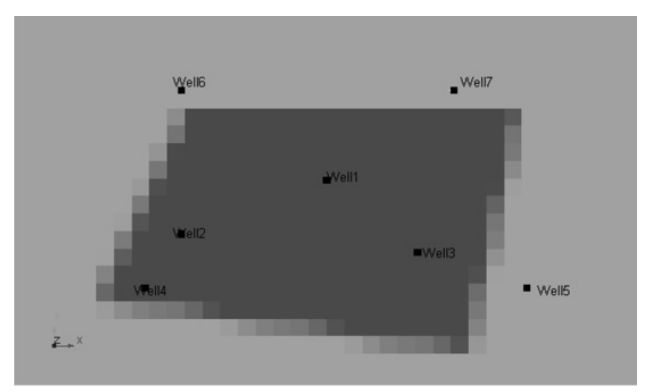

$a$

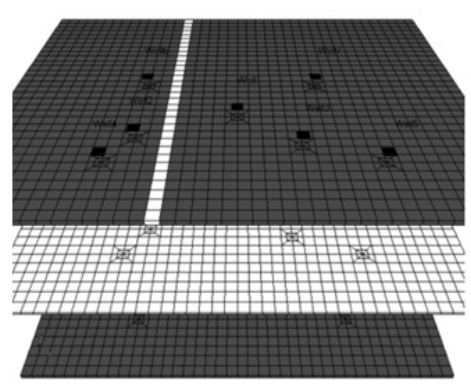

$c$

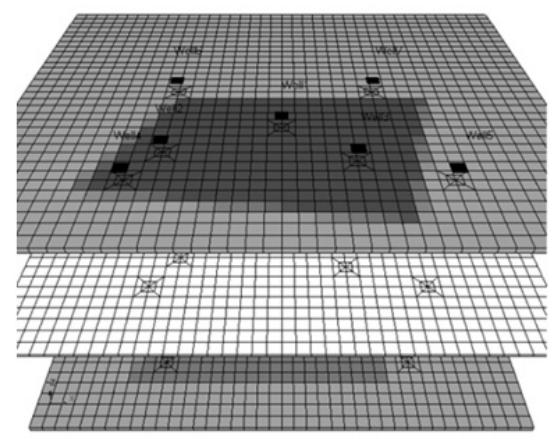

$b$

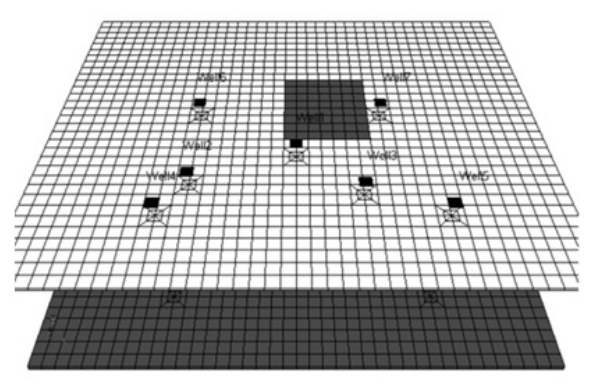

$d$

Fig. 2. Models to test procedures for determining the mutual influence of injection and production wells:

$a$ - the distribution of saturation in the upper layer and the location of the wells; $b$ - a layered view saturation in model $1 ; c-$ a layered view of permeability in model $2 ; d$-a layered view of permeability in model 3 (with a removed upper layer)

Puc. 2. Модели для тестирования процедуры определения взаимовлияния нагнетательных и добывающих скважин:

$a$ - распределение насыщенности в верхнем слое и расположение скважин; $\sigma$ - послойный вид насыщенности в модели $1 ; 8$ - послойный вид проницаемости в модели $2 ; 2-$ послойный вид проницаемости в модели 3 (со снятым верхним слоем) 
Thus, Well 1 takes off only from the upper layer, Well 2 takes off from both the top and the bottom layers, and Well 3 takes off only from the bottom layer. In turn, Well 4, Well 5 and Well 6 inject into the upper layer and Well 7 injects into the lower layer.

Fig. 3 presents the results of procedures to determine the influence of wells for Model 1. It can be seen that Well 1 is mainly influenced by Well 6 (as Well 7 injects into the layer separated by an impermeable interlayer and Well 4 and Well 5 are separated by production wells, namely Well 2 and Well 3). Well 2 is affected by Well 6 and Well 4 (with an influence coefficient of 2.5-2.8), and Well 3 is affected by Well 7 (which, despite the fact that it is further located, injects in the same layer from which production Well 3 takes off, and this layer is separated by impermeable interlayers).

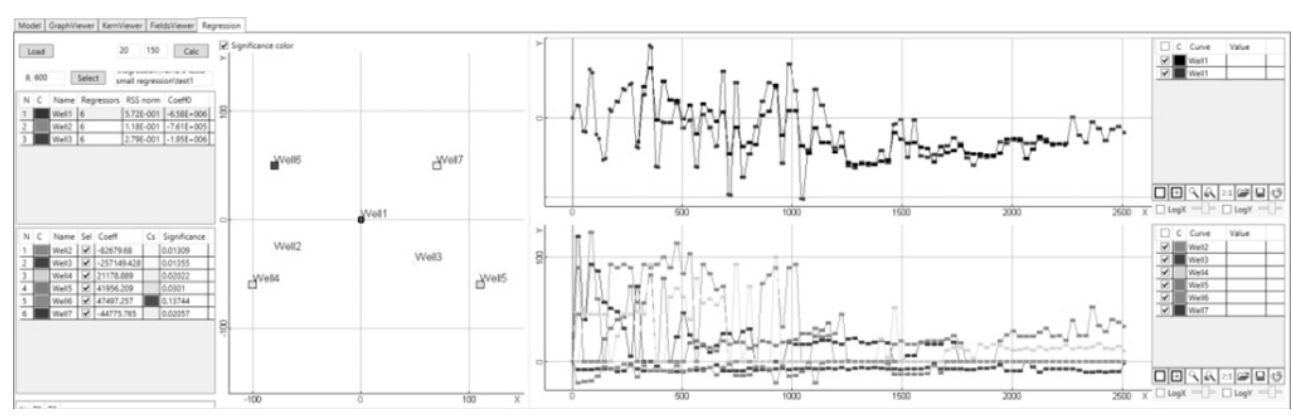

$a$

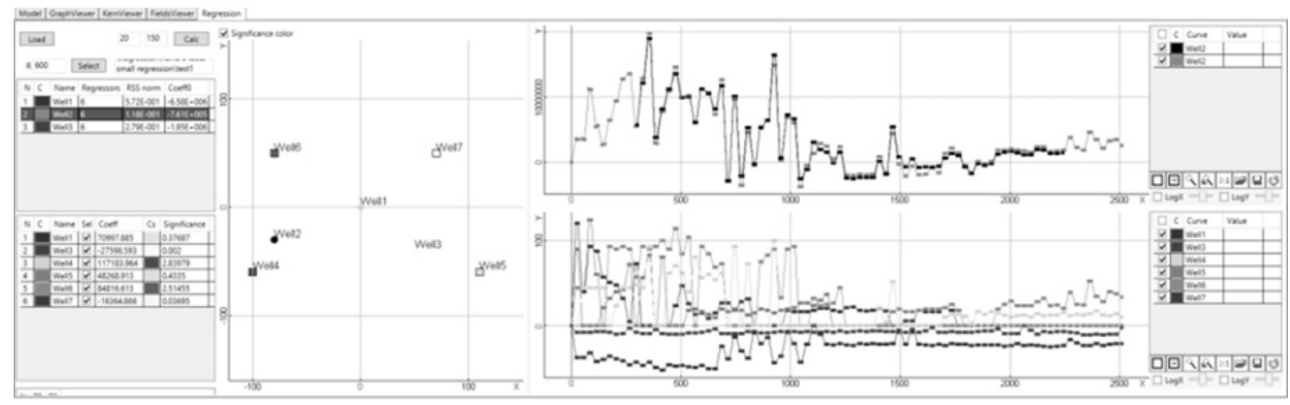

$b$

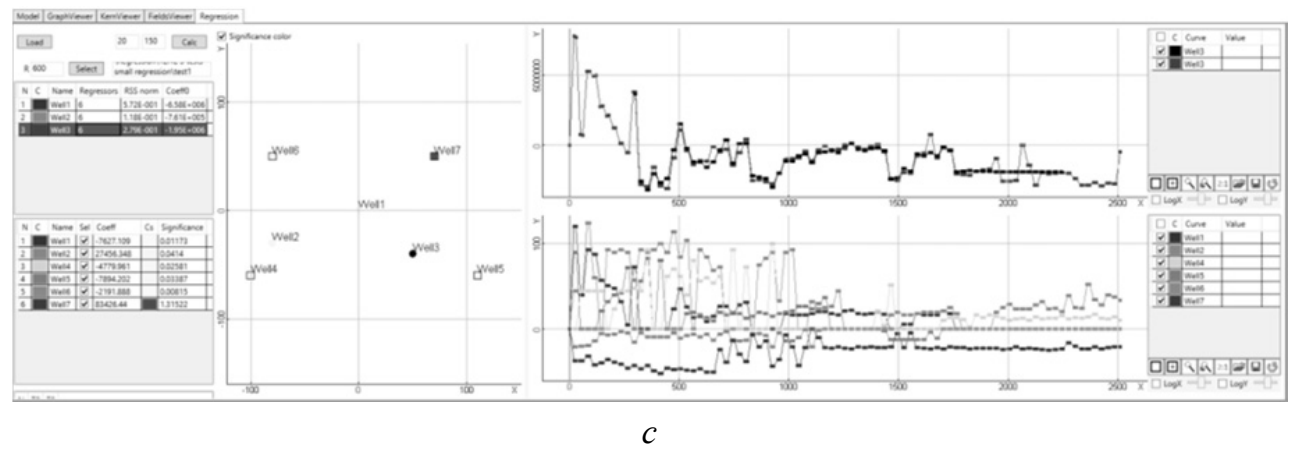

Fig. 3. The influence of Well $1(a)$, Well $2(b)$ and Well $3(c)$ according to the synthesized model 1

Puc. 3. Влияние на скважины Well 1 (a), Well 2 (б) и Well 3 (в) по данным, синтезированным для модели 1 
Fig. 4, $a, b$ shows the results for model 2. It can be seen that the influence on Well 1 dropped sharply since it became a separate impermeable "barrier", and the influence on Well 2, on the contrary, increased dramatically (the influence coefficient became 3.5). Fig. 4, $c$ presents the results of model 3. It can be seen that due to the appearance of permeable zones in the interlayer Well 3 became affected by Well 5 which injects into the upper layer in addition to Well 7.

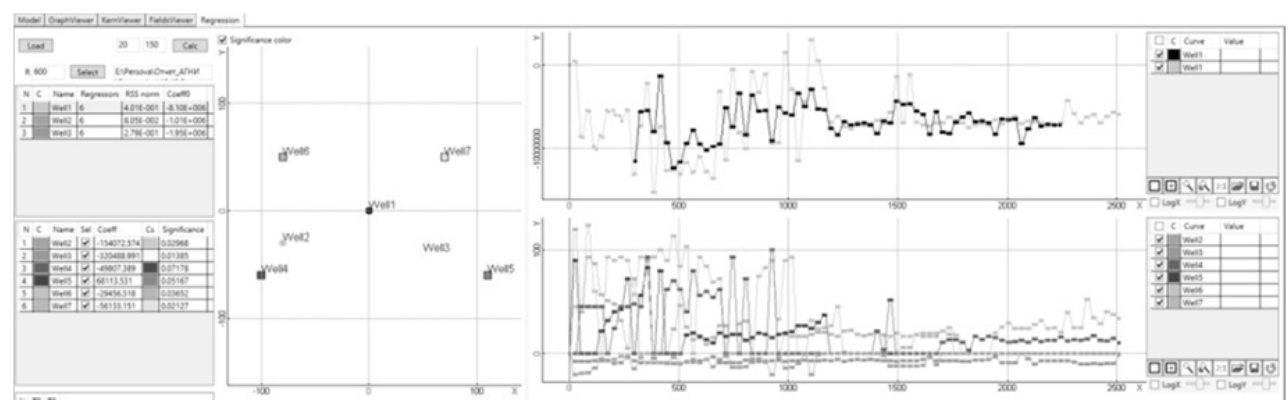

$a$

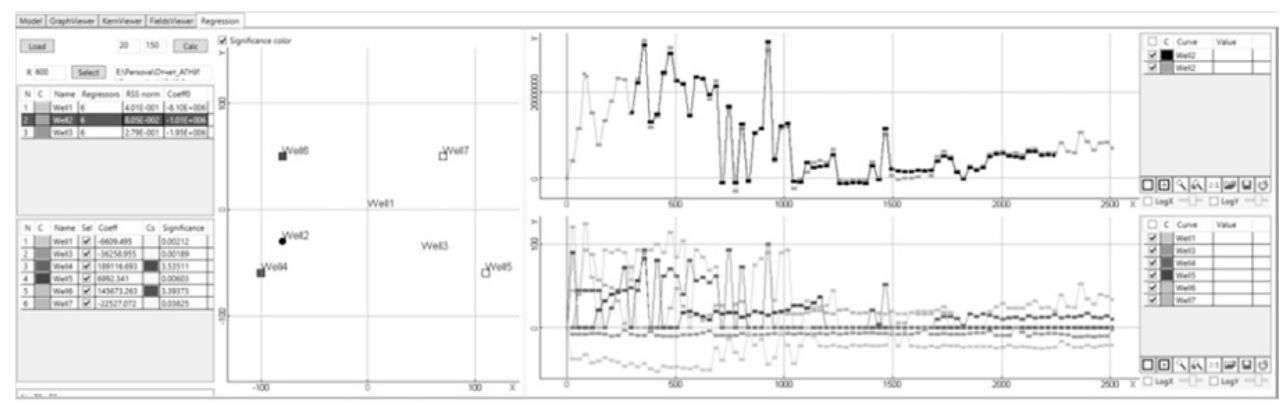

b

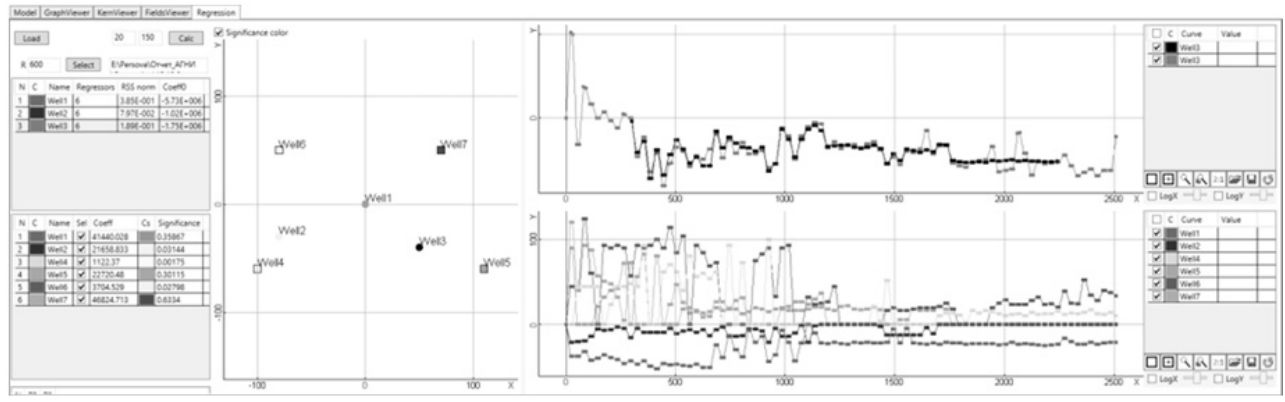

Fig. 4. The influence of Well $1(a)$ and Well $2(b)$ according to the synthesized model 2, and Well $3(c)$ according to the synthesized model 3

Puc. 4. Влияние на скважины Well 1 (a) и Well 2 (б) по данным, синтезированным для модели 2, и на скважину Well 3 (в) по данным, синтезированным для модели 3

\section{CONCLUSION}

The method for determining the influence of injection wells on production wells is presented in the paper. The aforementioned method of finite-element modeling of hydrodynamic processes avoids the disadvantages of the classical Galerkin 
method and guarantees the observance of the law of mass balance of the filtered components of the mixture. The conducted study of characteristic synthetic models allows us to conclude that the estimated influence of wells corresponds to the physics of the process. This confirms the correctness of the developed procedure for analyzing the interaction of injection and production wells, and also indirectly confirms the correctness of the implementation of the module for solving direct problems. Creating a hydrodynamic model, carrying out calculations, as well as analyzing mutual influence of wells, are implemented in an automated softwareinformation system.

\section{REFERENCES}

1. Clemens T., Kienberger G., Persaud M., Suri A., Sharma M.M., Boschi M., Øverland A.M. Optimizing water-injection design in a shallow offshore reservoir. SPE Production and Operations, 2017, vol. 32, no. 4, pp. 551-563.

2. Bautista J.F., Taleghani A.D. Prediction of formation damage at water injection wells due to channelization in unconsolidated formations. Journal of Petroleum Science and Engineering, 2018, vol. 64, pp. 1-10. DOI: 10.1016/j.petrol.2017.12.073.

3. Vasil'ev V.V. Ispol'zovanie rezul'tatov otsenki vzaimovliyaniya dobyvayushchikh i nagnetatel'nykh skvazhin dlya optimizatsii zavodneniya [Use of results of an estimation of producing and injection wells interference for the waterflooding optimization]. Neftyanoe khozyaistvo - Oil Industry, 2009, no. 6, pp. 30-32. (In Russian).

4. Mosleh M.H., Govindan R., Shi J., Durucan S., Korre A. The use of polymer-gel remediation for CO2 leakage through faults and fractures in the caprock. Energy Procedia, 2017, vol. 114, pp. 4164-4171. DOI: 10.1016/j.egypro.2017.03.1557.

5. Nekrasov A.S., Potekhin D.V., Shilov A.V., Prisyazhnyuk M.A. Obosnovanie polozheniya vodoneftyanogo kontakta pri geologo-gidrodinamicheskom modelirovanii zalezhei nefti i gaza [Substantiation of oil-water contact location for the purposes of its geological and hydro-dynamic modeling]. Geomodel 2016 - 18th Science and Applied Research Conference on Oil and Gas Geological Exploration and Development, Gelendzhik, 2016, pp. 156-161. DOI: 10.3997/2214-4609.201602239. (In Russian).

6. Cao H., Crumpton P.I., Schrader M.L. Efficient general formulation approach for modeling complex physics. SPE Reservoir Simulation Symposium 2009, The Woodlands, TX, 2009, vol. 2, pp. 1075-1086. DOI: 10.2118/119165-MS.

7. Stepanov S.V., Sokolov S.V., Ruchkin A.A., Stepanov A.V., Knyazev A.V., Korytov A.V. Problematika otsenki vzaimovliyaniya dobyvayushchikh i nagnetatel'nykh skvazhin na osnove matematicheskogo modelirovaniya [Considerations on mathematical modeling of producer-injector interference]. Vestnik Tyumenskogo gosudarstvennogo universiteta. Fiziko-matematicheskoe modelirovanie. Neft', gaz, energetika - Tyumen State University Herald. Physical and Mathematical Modeling. Oil, Gas, Energy, 2018, vol. 4, no. 3, pp. 146-164. DOI: 10.21684/2411-7978-2018-4-3-146-164.

8. Zhang R.H., Zhang L.H., Luo J.X., Yang Z.D., Xu M.Y. Numerical simulation of water flooding in natural fractured reservoirs based on control volume finite element method. Journal of Petroleum Science and Engineering, 2016, vol. 146, pp. 1211-1225. DOI: 10.1016/j.petrol.2016.08.024.

9. Nick H.M., Matthäi S.K. A hybrid finite-element finite-volume method with embedded discontinuities for solute transport in heterogeneous media. Vadose Zone Journal, 2011, vol. 10, no. 1, pp. 299-312. DOI: $10.2136 /$ vzj2010.0015.

10. Nick H.M., Matthäi S.K. Comparison of three FE-FV numerical schemes for single- and two-phase flow simulation of fractured porous media. Transport in Porous Media, 2011, vol. 90, no. 2, pp. 421-444. DOI: 10.1007/s11242-011-9793-y.

11. Abushaikha A.S., Blunt M.J., Gosselin O.R., Pain C.C., Jackson M.D. Interface control volume finite element method for modelling multi-phase fluid flow in highly heterogeneous and fractured reservoirs. Journal of Computational Physics, 2015, vol. 298, pp. 41-61. DOI: 10.1016/j.jcp.2015.05.024.

12. Aziz K., Settari A. Petroleum reservoir simulation. London, Applied Science Publishers, 1979 (Russ. ed.: Aziz Kh., Settari E. Matematicheskoe modelirovanie plastovykh system. Moscow, Nedra Publ., 1982. 407 p.). 
13. Patrushev I.I., Persova M.G., Soloveychik Yu.G. [Research of the numerical method of modeling of three-dimensional multiphase flow]. Obrabotka informatsii i matematicheskoe modelirovanie: materialy Rossiiskoi nauchno-tekhnicheskoi konferentsii [Proceedings of Russian scientific conference "Information Processing and Mathematical Modelling"], Novosibirsk, 26-27 April, 2018, pp. 85-92. (In Russian).

14. Soloveychik Yu.G., Royak M.E., Persova M.G. Metod konechnykh elementov dlya skalyarnykh $i$ vektornykh zadach [The finite element method for the solution of scalar and vector problems]. Novosibirsk, NSTU Publ., 2007. 896 p.

15. Persova M.G., Soloveichik Yu.G., Grif A.M., Patrushev I.I. Flow balancing in FEM modelling of multi-phase flow in porous media. 2018 14th International conference on actual problems of electronic instrument engineering (APEIE)-44894 proceedings, Novosibirsk, October 2-6, 2018, vol. 1, pt. 4, pp. 205-211.

16. Grif A.M., Persova M.G. Postroenie poverkhnostei sloev geologicheskoi modeli neftyanogo mestorozhdeniya dlya modelirovaniya protsessa mnogofaznoi fil'tratsii [Construction of the layer surfaces of a geological model of an oil field for modeling the multiphase filtration process]. Nauka. Tekhnologii. Innovatsii [Science. Technologies. Innovation], Novosibirsk, December 3-7, 2018. Novosibirsk, NSTU Publ., 2018, pt. 2, pp. 121-125.

Alexander M. Grif, a graduate student at the Department of Applied Mathematics, Faculty of Applied Mathematics and Computer Science, Novosibirsk State Technical University. His research interests are currently focused on finite-element modeling of physical processes. He has published 17 scientific papers. Email: alexgrif@inbox.ru

Marina G. Persova, a professor at the Department of Applied Mathematics, Faculty of Applied Mathematics and Computer Science, Novosibirsk State Technical University. Her research interests include finite element modeling and solution of inverse problems of mathematical physics. She has published more than 150 scientific papers and educational manuals. Email: persova@ami.nstu.ru

Yuri G. Soloveichik, head of the Department of Applied Mathematics, Faculty of Applied Mathematics and Computer Science, Novosibirsk State Technical University. His research interests cover finite element modeling and solution of inverse problems of mathematical physics. $\mathrm{He}$ is the author of more than 150 scientific and educational publications. Email: soloveychik@ami.nstu.ru

DOI: $10.17212 / 1814-1196-2019-4-31-44$

\section{Определение влияния нагнетательных скважин на добывающие в динамике их работы с использованием гидродинамического моделирования *}

\section{А.М. ГРИФ $\Phi^{a}$, М.Г. ПЕРСОВА}

630073, РФ, г. Новосибирск, пр. Карла Маркса 20, Новосибирский государственный технический университет

aalexgrif@inbox.ru ${ }^{b}$ persova@ami.nstu.ru ${ }^{c}$ soloveychik@ami.nstu.ru

Рассматривается способ для определения взаимовлияния группы добывающих и нагнетательных скважин с использованием модуля гидродинамического моделирования. Полученные результаты взаимовлияния широко используются в практике - от поддержания пластового давления до эффективной оптимизации заводнения. Для моделирования процесса фильтрации многофазной смеси используются метод конечных элементов и специальная технология балансировки потоков через границы ячеек конечноэлементной сетки. Метод балансировки основан на подборе корректирующих добавок, удовлетворя-

\footnotetext{
* Статья получена 15 октября 2019 года.
} 
ющих минимуму функционала баланса объемов фильтрующейся смеси с регуляризацией. В модели взаимовлияния скважин используются полученная в результате гидродинамического моделирования зависимость устьевого давления, а также объемы закачиваемой и/или отбираемой смеси (с разными знаками). Для интересующей добывающей скважины устьевое давление аппроксимируется функцией от объемов закачиваемой смеси на группе соседних скважин. Коэффициенты регрессии находятся с помощью метода наименьших квадратов. Приведены исследования применения метода на трех характерных задачах, эмулирующих работу добывающих и нагнетательных скважин. Для оценки степени влияния соседней скважины на интересующую скважину вводится критерий значимости (коэффициент влияния) в виде отношений остаточных сумм квадратов отклонений. Результаты расчетов свидетельствуют о том, что оцененное влияние скважин соответствует физике процесса - это подтверждает корректность работы разработанной процедуры анализа взаимовлияния нагнетательных и добывающих скважин, а также косвенно подтверждает правильность реализации модуля решения прямых задач. Задание гидродинамической модели, проведение расчетов, а также анализ взаимовлияния скважин реализованы в интерактивном режиме в автоматизированной программноинформационной системе.

Ключевые слова: гидродинамическое моделирование, фильтрация, метод конечных элементов, балансировка потоков, взаимодействие скважин, регрессия, влияние, информационная система

\section{СПИСОК ЛИТЕРАТУРЫ}

1. Optimizing water-injection design in a shallow offshore reservoir / T. Clemens, G. Kienberger, M. Persaud, A. Suri, M.M. Sharma, M. Boschi, A.M. Øverland // SPE Production and Operations. - 2017. - Vol. 32, N 4. - P. 551-563.

2. Bautista J.F., Taleghani A.D. Prediction of formation damage at water injection wells due to channelization in unconsolidated formations // Journal of Petroleum Science and Engineering. 2018. - Vol. 64. - P. 1-10. - DOI: 10.1016/j.petrol.2017.12.073.

3. Васильев В.В. Использование результатов оценки взаимовлияния добывающих и нагнетательных скважин для оптимизации заводнения // Нефтяное хозяйство. -2009 . - № 6 . C. $30-32$.

4. The use of polymer-gel remediation for $\mathrm{CO} 2$ leakage through faults and fractures in the caprock / M.H. Mosleh, R. Govindan, J. Shi, S. Durucan, A. Korre // Energy Procedia. - 2017 Vol. 114. - P. 4164-4171. - DOI: 10.1016/j.egypro.2017.03.1557.

5. Обоснование положения водонефтяного контакта при геолого-гидродинамическом моделировании залежей нефти и газа / А.С. Некрасов, Д.В. Потехин, А.В. Шилов, М.А. Присяжнюк // Geomodel 2016 - 18th Science and Applied Research Conference on Oil and Gas Geological Exploration and Development. - Gelendzhik, 2016. - P. 156-161. - DOI: 10.3997/22144609.201602239.

6. Cao H., Crumpton P.I., Schrader M.L. Efficient general formulation approach for modeling complex physics // SPE Reservoir Simulation Symposium 2009. - The Woodlands, TX, 2009. Vol. 2. - P. 1075-1086. - DOI: 10.2118/119165-MS.

7. Проблематика оценки взаимовлияния добывающих и нагнетательных скважин на основе математического моделирования / С.В. Степанов, С.В. Соколов, А.А. Ручкин, А.В. Степанов, А.В. Князев, А.В. Корытов // Вестник Тюменского государственного университета. Физико-математическое моделирование. Нефть, газ, энергетика. - 2018. - Т. 4,. № 3. - С. 146-164. DOI: $10.21684 / 2411-7978-2018-4-3-146-164$.

8. Numerical simulation of water flooding in natural fractured reservoirs based on control volume finite element method / R.H. Zhang, L.H. Zhang, J.X. Luo, Z.D. Yang, M.Y. Xu // Journal of Petroleum Science and Engineering. - 2016. - Vol. 146. - P. 1211-1225. - DOI: 10.1016/j.petrol.2016.08.024.

9. Nick H.M., Matthäi S.K. A hybrid finite-element finite-volume method with embedded discontinuities for solute transport in heterogeneous media // Vadose Zone Journal. - 2011. - Vol. 10, N 1. - P. 299-312. - DOI: 10.2136/vzj2010.0015. 
10. Nick H.M., Matthäi S.K. Comparison of three FE-FV numerical schemes for single- and two-phase flow simulation of fractured porous media // Transport in Porous Media. - 2011. - Vol. 90, N 2. - P. 421-444. - DOI: 10.1007/s11242-011-9793-y.

11. Interface control volume finite element method for modelling multi-phase fluid flow in highly heterogeneous and fractured reservoirs / A.S. Abushaikha, M.J. Blunt, O.R. Gosselin, C.C. Pain, M.D. Jackson // Journal of Computational Physics. - 2015. - Vol. 298. - P. 41-61. DOI: $10.1016 /$ j.jcp.2015.05.024.

12. Азиз X., Сеттари Э. Математическое моделирование пластовых систем: пер. с англ. М.: Недра, 1982. - 407 с.

13. Патрушев И.И., Персова М.Г., Соловейчик Ю.Г. Исследование численного метода трехмерного моделирования процесса многофазной фильтрации // Обработка информации и математическое моделирование: материалы Российской научно-технической конференции (Новосибирск, 26-27 апр. 2018 г.). - Новосибирск: Изд-во СибГУТИ, 2018. - С. 85-92.

14. Соловейчик Ю.Г., Рояк М.Э., Персова М.Г. Метод конечных элементов для скалярных и векторных задач. - Новосибирск: Изд-во НГТУ, 2007. - 869 с.

15. Flow balancing in FEM modelling of multi-phase flow in porous media / M.G. Persova, Yu.G. Soloveichik, A.M. Grif, I.I. Patrushev // Актуальные проблемы электронного приборостроения (АПЭП-2018) $=2018$ 14th International conference on actual problems of electronic instrument engineering (APEIE)-44894 proceedings, Новосибирск, 2-6 октября 2018 г.: в 8 т. - Новосибирск, 2018. - T. 1, ч. 4. - С. 205-211.

16. ГрифА.М., Персова М.Г. Построение поверхностей слоев геологической модели нефтяного месторождения для моделирования процесса многофазной фильтрации // Наука. Технологии. Инновации: сборник научных трудов: в 9 ч., Новосибирск, 3-7 декабря 2018 г. Новосибирск: Изд-во НГТУ, 2018. - Ч. 2. - С. 121-125.

Для цитирования:

Гриф А.М., Персова М.Г., Соловейчик Ю.Г. Определение влияния нагнетательных скважин на добывающие в динамике их работы с использованием гидродинамического моделирования // Научный вестник НГТУ. - 2019. - № 4 (77). - C. 31-44. - DOI: 10.17212/1814-11962019-4-31-44. - Текст англ.

For citation:

Grif A.M., Persova M.G., Soloveychik Y.G. Determination of the effect of injection wells on production wells in their work dynamics by using hydrodynamic modeling. Nauchnyi vestnik Novosibirskogo gosudarstvennogo tekhnicheskogo universiteta - Science bulletin of the Novosibirsk state technical university, 2019, no. 4 (77), pp. 31-44. DOI: 10.17212/1814-1196-2019-4-31-44.

ISSN 1814-1196, http://journals.nstu.ru/vestnik Science Bulletin of the NSTU Vol. 77, No 4, 2019, pp. 31-44 